\title{
Food web structures of subtidal benthic muddy habitats: evidence of microphytobenthos contribution supported by an engineer species
}

\author{
Carinne Rigolet ${ }^{1,2}$, Eric Thiébaut ${ }^{2,3}$, Stanislas F. Dubois ${ }^{1, *}$ \\ ${ }^{1}$ Institut Francais de Recherche pour l'Exploitation de la Mer (IFREMER), \\ Dynamiques de l'Environnement Cótier (DYNECO), Laboratoire Ecologie Benthique, Technopole Brest-Iroise, BP 70, 29280 \\ Plouzané, France \\ ${ }^{2}$ Centre National de la Recherche Scientifique (CNRS), UMR 7144, Adaptation et Diversité en Milieu Marin, \\ Station Biologique de Roscoff, Place Georges Teissier, 29680 Roscoff, France
}

${ }^{3}$ Université Pierre et Marie Curie (UPMC), Université Paris 06, UMR 7144, Station Biologique de Roscoff, 29680 Roscoff, France

\begin{abstract}
Stable carbon and nitrogen isotopic composition $\left(\delta^{13} \mathrm{C}\right.$ and $\left.\delta^{15} \mathrm{~N}\right)$ of benthic organisms was investigated to understand the effects of a gregarious tubicolous amphipod species (Haploops nirae) on benthic food web structures and test whether drastic changes in species composition cause changes in food web structure. The habitat engineered by this species was sampled and compared with the adjacent uncolonized Amphiura filiformis muddy habitat in winter and summer. The isotopic signatures of macrofaunal and megafaunal species associated with both habitats were analysed along with potential food sources at each sampling period. Similar food web structures for each habitat (and each season), with high $\delta^{15} \mathrm{~N}$ ranges spanning over 3 trophic levels, were reported although omnivory was less frequent in the $H$. nirae habitat. The amphipod $H$. nirae appears to play a baseline role, with the lowest $\delta^{15} \mathrm{~N}$ values and $\delta^{13} \mathrm{C}$ values indicating that it primarily feeds on phytoplankton. Bayesian mixing models were used to estimate the contributions of potential food sources to the diet of the species accounting for most of the biomass in each habitat and showed that the epibionts covering tube mats are a key contribution to the food webs of both habitats. Identified as benthic diatoms, they may minimize interspecific food competition between dominant suspension feeders such as Polititapes virgineus or $H$. nirae within a habitat. This finding highlights the contribution of microphytobenthic producers to subtidal ( $30 \mathrm{~m}$ deep) muddy habitat food webs, suggesting that the mucopolysaccharides composing the $H$. nirae tubes support the growth of a heterotrophic diatom population. As an engineer species, $H$. nirae acts as a facilitator for diatoms which ultimately sustain the secondary production of the $H$. nirae habitat as well as the immediate surrounding habitats.
\end{abstract}

KEY WORDS: Stable isotopes · Gregarious amphipod · Source contribution · Haploops $\cdot$ Benthic diatoms $\cdot$ Navicula

Resale or republication not permitted without written consent of the publisher

\section{INTRODUCTION}

Coastal zones are considered among the most productive marine systems in the world, with both high ecological and high economic values. They offer a wide variety of ecosystem services for humans but also sustain ecological processes of primary impor- tance for marine wildlife such as nutrient regulation, carbon sequestration and detoxification of polluted waters (Costanza et al. 1997, Gattuso et al. 1998, Barbier et al. 2011). Coastal ecosystems are also known to support particularly species-rich and abundant benthic communities, resulting in areas of high benthic secondary production which are of major 
importance for supporting nursery grounds and feeding areas for most coastal and many oceanic fish species (Kopp et al. 2013). The importance of coastal systems in sustaining marine wildlife has consequently required a much better knowledge of biological and ecological processes in coastal systems. As reviewed in Duffy et al. (2007), the trophic complexity within trophic levels (TLs; food chain width and variety of food sources) and across TLs (food chain length and omnivory) are essential elements to understand how biodiversity changes affect ecosystem functioning. Yet the understanding of trophic dynamics and pathways in coastal systems remains partly unknown. Indeed, while primary production in the open ocean is dominated only by phytoplankton, a large variety of primary producers (e.g. macrophytes, salt marsh plants, mangroves, seagrass beds and microphytobenthos [MPB]) contribute to the organic matter (OM) sedimentary pool available for benthic consumers in coastal ecosystems (Evrard et al. 2012). Unlike in shores and estuaries, where benthic primary production through MPB plays a key role in benthic food webs (Riera et al. 1996, Dubois et al. 2007, Lefebvre et al. 2009), microphytobenthic primary producers are disregarded in subtidal benthic food webs, despite evidence that carbon isotope $\left(\delta^{13} \mathrm{C}\right)$-enriched compositions of benthic suspension and deposit feeders cannot solely be explained by phytoplankton or macroalgae sources (e.g. Grall et al. 2006, Carlier et al. 2007). Few studies, however, have emphasized the potential role of MPB in the trophic food webs of different coastal habitats such as estuarine systems, mudflats (Middleburg et al. 2000) or shallow sandy permeable sediments (Evrard et al. 2010). Stable carbon and nitrogen isotope ratios have proven to be a powerful tool in evaluating feeding relationships and OM flows through marine food webs (Dubois \& Grall 2013). As stable isotopes are frequently used to understand feeding behaviour and trophic relationships between species (Peterson \& Fry 1987), they can also be used at the community scale to describe the overall structure of a food web such as food web length or trophic niche space (Bearhop et al. 2004, Cornwell et al. 2006, Layman et al. 2007a), for example providing valuable information on the health of the system (Layman et al. 2007b, Zambrano et al. 2010). However, stable isotopes (mostly carbon and nitrogen) have been more specifically used to disentangle trophic pathways in coastal systems by ranking the OM sources supporting food webs and to provide estimates of food source contributions to consumers' diets. When wisely used (but see recommendations in Fry 2013), the development of mixing models has greatly enhanced the power in isotopic tools (Phillips \& Gregg 2003, Parnell et al. 2010).

Some benthic coastal systems are considered to have particularly high ecological value (Wright \& Jones 2006, Voultsiadou et al. 2007), and these are often habitats which are physically modified by engineer species (as defined in Jones et al. 1994). Mangroves, seagrasses or coral reef habitats have been shown not only to enhance the local biodiversity of benthic and pelagic species but also to modify the availability of resources for other species (Berkenbusch \& Rowden 2007). Ecosystem engineers often are key species in ecosystem functioning. While their effects on the diversity of benthic communities have been widely investigated (see review and references in Reise et al. 2009), only a few studies have paid attention to the consequences of ecosystem engineers on the structure of marine food webs. Yet, ecosystem engineers can induce changes in the intensity of biological interactions (mainly predation-prey interactions) (Irlandi \& Peterson 1991) or can alter the food supply to other organisms (Allen \& Williams 2003), thus having major consequences on flows of organic pathways in benthic coastal systems.

In South Brittany (France), a benthic community dominated by the gregarious tubicolous ampeliscid Haploops nirae forms dense tube mats in 2 main coastal ecosystems, namely the Bay of Concarneau and the Bay of Vilaine (Rigolet et al. 2014). H. nirae is the most abundant species in these bays and forms dense populations, with average densities ranging between about 1000 and 25000 ind. $\mathrm{m}^{-2}$ (Rigolet et al. 2012). While the presence of a Haploops community was reported during the first description of shallow benthic communities of southern Brittany (Glémarec 1969), recent acoustic surveys showed a significant increase in area of cover (Ehrhold et al. 2006). For example, the mapping of the Bay of Concarneau revealed a 5 -fold increase in $H$. nirae habitat surface between 1963 (650 ha, Glémarec 1969) and 2003 (3680 ha, Ehrhold et al. 2006). By investigating the consequences of this expansion on the benthic habitats, Rigolet et al. (2014) showed that $H$. nirae significantly modify sediment features (e.g. change in granulometry, increase in carbon and nitrogen organic content) and therefore deeply affect species diversity and benthic composition by creating an unusual and diverse macrofaunal assemblage. Analysis of species composition revealed that the Haploops community shared very few species with surrounding soft-sediment communities. Due to its effects on the physical and chemical properties of the sedimen- 
tary habitat, $H$. nirae can be defined as an ecosystem engineer (Reise et al. 2009). However, very little is known about its direct effect on food web functioning (e.g. resource availability) and whether changes in species composition can indirectly affect trophic pathways and food web structure. Several studies have provided evidence that dense populations of ampeliscids could play a major role in energy transfer in some marine systems, not only because they can affect benthic-pelagic coupling and have a major grazing impact on phytoplankton production (Grebmeier \& Mc Roy 1989, Rigolet et al. 2011) but also because they export a high production towards higher TLs (Franz \& Tanacredi 1992, Highsmith \& Coyle 1992). In this study, we sampled the diversity of benthic organisms associated with the Haploops habitat and the adjacent uncolonized Amphiura habitat over 2 seasons. We used stable carbon and nitrogen isotopes to investigate whether drastic changes in species composition also cause changes in food web structure and to identify the main trophic pathways and main food sources that support the macrofauna assemblages in these systems. More specifically, we aim to address here the following: (1) how the expansion of an engineer species, i.e. $H$. nirae, influences the food web structure of benthic habitats; and (2) how the presence of $H$. nirae controls the availability of food sources within and among habitats.

\section{MATERIALS AND METHODS}

\section{Study area and sampling strategy}

This study was conducted in the Bay of Concarneau, in the northern part of the Bay of Biscay (France) (Fig. 1). This area is sheltered by a succession of rocky islets and is characterized by softbottom substrata, spanning from muds to muddy sands, with a depth ranging from 15 to $35 \mathrm{~m}$ (Ménesguen 1980, Ehrhold et al. 2006). The western part of the bay (Mouton Islets and Glénan Islands) is composed of muddy sands and sandy muds, with the benthic community dominated by the echinoderm Amphiura filiformis. The central part of the bay, where currents are strongly reduced, is composed of pure mud supporting a dense population of the tubicolous amphipod Haploops nirae (hereafter referred to as Haploops).

To investigate the effects of Haploops tube mats on benthic trophic structure, we compared the food web structure of the H. nirae habitat (hereafter Haploops habitat) with the adjacent benthic and uncolonized Amphiura filiformis habitat (hereafter Amphiura habitat). Using a mapping survey of the seabed in the Bay of Concarneau based on geoacoustic approaches and complementary benthic biological grab samples (Ehrhold et al. 2006), we selected 6 stations distributed along 2 north-south transects reflecting an inshore-offshore gradient (Fig. 1). The 6 stations were sampled during 2 contrasting seasons: in winter (February 2010), when food inputs were particularly low and when the benthic fauna has a low metabolic activity, and in summer (August 2010), at the end of a period characterized by high supply of pelagic production in this area.

\section{Sample collection and laboratory processes}

To investigate the trophic structure within each habitat (i.e. Haploops and Amphiura), we collected the largest possible diversity of macrofaunal and megafaunal organisms for isotopic analyses at all stations of each community transect and for the 2 seasons. Macrofauna (individual size: 1 to $10 \mathrm{~mm}$ ) was sampled using a $0.1 \mathrm{~m}^{2}$ Van Veen grab (at least 2 grabs per station), and megafauna (individual size $>10 \mathrm{~mm}$ ) was sampled using a modified beam trawl $\left(\right.$ width $=2 \mathrm{~m}$, sampled surface $=$ ca. $\left.2300 \mathrm{~m}^{2}\right)($ Desaunay et al. 2006) with 1 trawl at each station.

All collected benthic organisms were carefully sorted on board and kept frozen. In the laboratory, organisms were identified to the lowest taxonomic level (i.e. generally at the species level). Species names were checked using the World Register of Marine Species database (www.marinespecies.org, accessed 28 October 2013). Isotopic analyses were then performed on muscle tissue samples for megafauna and large macrofauna. The whole body (gut dissected) was used for smaller species. In rare instances, several individuals were pooled to match the minimum weight required for stable isotope analyses. All samples were rinsed with Milli-Q water and freeze-dried. Three replicates were analysed. For calcified organisms (crustaceans and echinoderms), a subsample was acidified $(10 \% \mathrm{HCl})$ to remove any inorganic carbonates, then rinsed with distilled water and freeze-dried again for ${ }^{13} \mathrm{C}$ values (a subsample was left untreated for ${ }^{15} \mathrm{~N}$ value). We used the mean isotopic value of organisms for each habitat by pooling organisms found in 2 or 3 stations of each transect. The mean isotopic value was considered to be a better estimate of the whole habitat and to account for any spatial variability. 


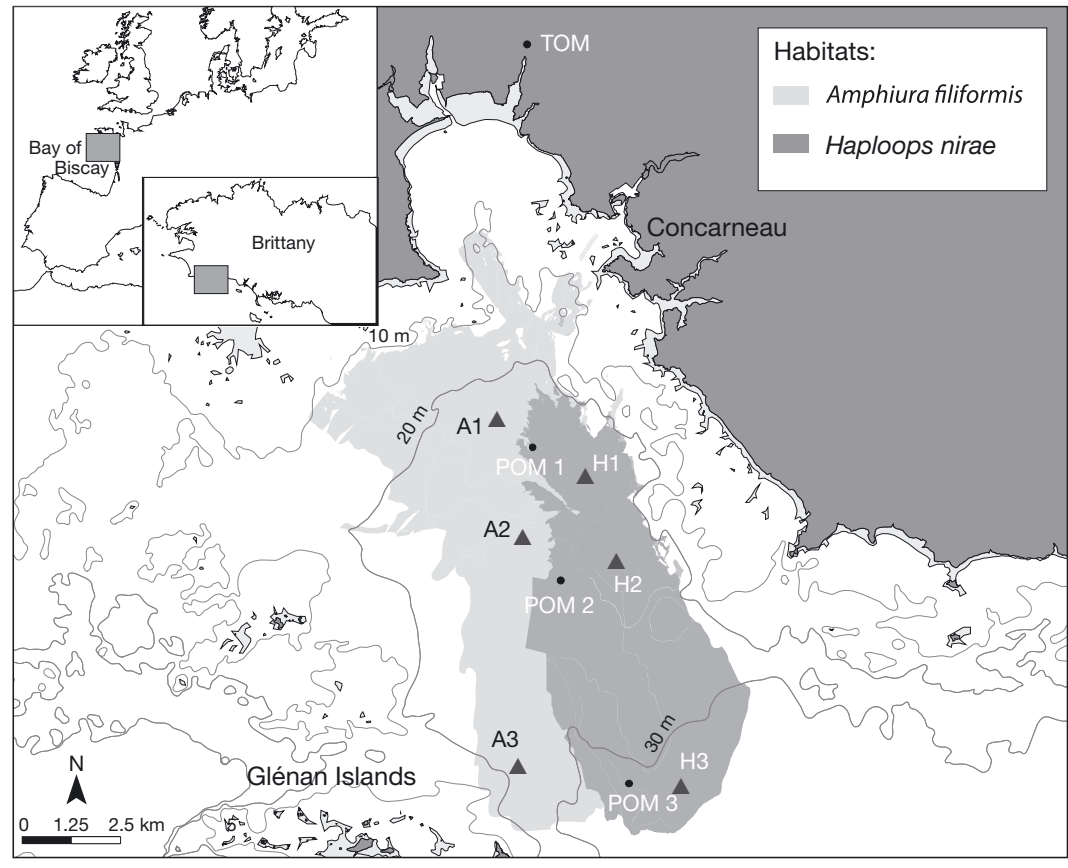

Fig. 1. Spatial distribution of the subtidal benthic habitat of the Bay of Concarneau and the 6 stations sampled seasonally along 2 transects (i.e. within the Haploops habitat [H1, H2, H3] and within the adjacent Amphiura habitat [A1, A2, A3]). Sampling stations for the benthic fauna are labelled with triangles, and sampling stations for water column phytoplankton (particulate organic matter, POM) and terrestrial inputs (terrestrial organic matter, TOM) are labelled with dots. Contours of benthic habitats are retrieved from previous acoustic and benthic survey mappings (Ehrhold et al. 2006) muddy, turbid waters (Le Loc'h et al. 2008). Consequently, most of the OM available for benthic primary consumers was assumed to originate from the suspended particulate organic matter (POM) (composed mainly of phytoplankton) sedimenting from upper water layers and from sedimented organic matter (SOM). However, close observations of Haploops tubes revealed that the surface of tubes was covered with brown epibionts (hereafter EPI), especially during spring blooms, identified as benthic diatom mats that belong to the genus Navicula (R. Siano pers. comm.) (Fig. 2). Benthic diatoms attached to Haploops tubes were also considered as a potential food source. In addition, macroalgal fragments and detritus originating from adjacent rocky islets (i.e. Glenan and Moutons) were caught in some trawls and were also considered as a potential food source for benthic organisms, even though sampled stations were below the photic limit required by attached macroalgae for growth (ca. $35 \mathrm{~m}$ deep).

All potential sources of OM available for the benthic fauna were collected for isotopic analyses. Terrestrial inputs of organic matter (TOM) are very limited in this area, as it receives freshwater inputs from small rivers only (i.e. mean monthly discharge $<1 \mathrm{~m}^{3} \mathrm{~s}^{-1}$ ). Because of a reduced light input, subtidal soft-bottom systems are commonly assumed to host very low benthic primary production, especially in

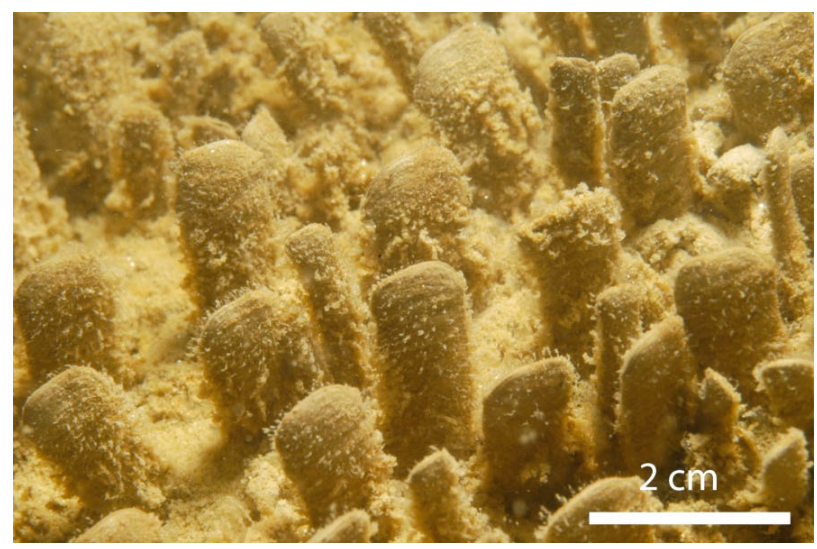

Fresh water was collected at 1 site located at the mouth of 1 small river for TOM analysis. Marine surface water was collected using Niskin bottles for POM analysis at stations along an inshore-offshore transect (Fig. 1) in between the 2 habitats which shared the same water masses. Water samples were prefiltered on a $100 \mu \mathrm{m}$ mesh to remove small animals such as zooplankton and then filtered on pre-

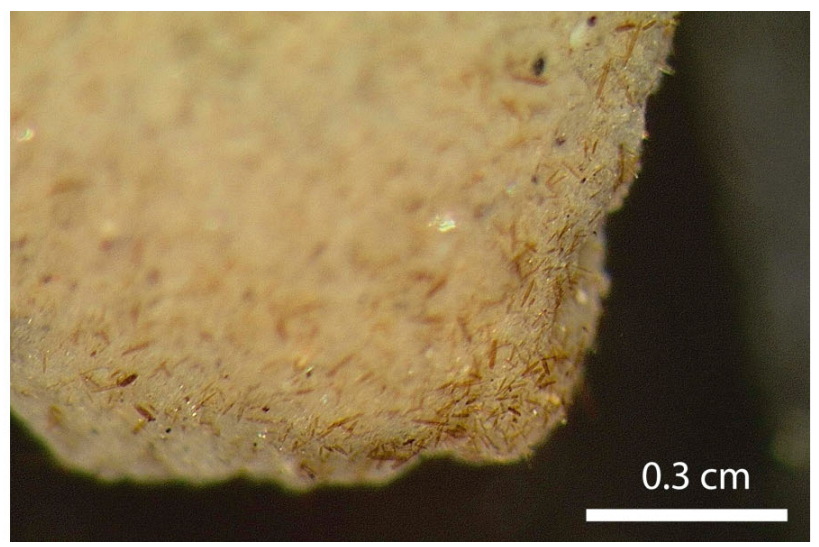

Fig. 2. Left: close-up of several Haploops nirae tubes protruding a few centimetres above the sediment (May 2010). Right: close-up of a distal end of a $H$. nirae tube under a dissecting scope showing numerous Navicula sp. diatoms (appearing as dark brown sticks) (May 2012) 
combusted GFF filters $\left(4 \mathrm{~h}, 550^{\circ} \mathrm{C}\right)$. Half of the GFF filters were acidified with $10 \mathrm{~N} \mathrm{HCl}$ fumes to remove traces of inorganic carbonates. SOM was sampled at each of the 6 stations using a Reineck corer to extract an undisturbed sediment core; from each core, 2 subcores were extracted to analyse both the isotopic composition of the OM and the chl $a$ and phaeopigment content. For the 3 Haploops stations (H1, H2 and H3, Fig. 1), the surfaces of several tubes were gently scraped with a razor blade under a dissecting scope and collected with distilled water. For both SOM and EPI samples, a subsample was acidified $(10 \% \mathrm{HCl})$ to remove inorganic carbonates $\left({ }^{13} \mathrm{C}\right)$, and the rest was left untreated $\left({ }^{15} \mathrm{~N}\right)$. Molar carbon to nitrogen $(\mathrm{C}: \mathrm{N})$ ratios were calculated from the percent carbon and percent nitrogen values obtained from acidified and untreated sediment samples, respectively. Chl $a$ and phaeopigment contents were estimated using the monochromatic technique (Lorenzen 1967) as described in Aminot \& Kérouel (2004). Finally, brown, red and green stranded macroalgae were collected from trawls in summer only, as very little macroalgae was noticed during winter.

\section{Isotopic analyses}

After freeze-drying, each sample was ground to a homogeneous powder, and $1 \mathrm{mg}$ was weighed in tin capsules for isotopic analyses. $\delta^{13} \mathrm{C}$ and $\delta^{15} \mathrm{~N}$ compositions were then measured with a stable isotope ratio mass spectrometer (Finnigan MAT Delta Plus), operating in continuous-flow mode, coupled to an elemental analyser (Carlo Erba NC2500, Cornell University Stable Isotope Laboratory). Isotopic ratios for carbon and nitrogen were expressed using the standard $\delta$ notation according to the following equation:

$$
\delta \mathrm{X}=\left[\left(R_{\text {sample }} / R_{\text {reference }}\right)-1\right] \times 1000(\%)
$$

where $\mathrm{X}={ }^{13} \mathrm{C}$ or ${ }^{15} \mathrm{~N}$, and $R={ }^{13} \mathrm{C} /{ }^{12} \mathrm{C}$ for carbon and ${ }^{15} \mathrm{~N} /{ }^{14} \mathrm{~N}$ for nitrogen. The reference for carbon was Vienna Pee Dee Belemnite $\left(\delta^{13} \mathrm{C}=0 \%\right)$, and the reference for nitrogen was atmospheric nitrogen $\left(\delta^{15} \mathrm{~N}=\right.$ $0 \%$ ). The analytical precision was $0.2 \%$ for both nitrogen and carbon.

\section{Data analyses}

To provide a detailed description of the structure of the food web associated with both habitats, macrofaunal and megafaunal species were classified into 5 trophic groups: suspension feeders, surface depo- sit feeders, subsurface deposit feeders, omnivorescarnivores and grazers. Trophic information on species were gathered from several scientific publications and from the Biological Traits Information Catalogue developed by the Marine Life Information Network (www.marlin.ac.uk/biotic).

The nitrogen isotope ratio is commonly used to estimate the trophic position of aquatic consumers (Cabana \& Rasmussen 1996, Vander Zanden et al. 1997, Post 2002), and organisms tend to fractionate nitrogen positively by 3 to $4 \%$ (Minagawa \& Wada 1984, Post 2002). In this context, Vander Zanden \& Rasmussen (2001) showed that the $\delta^{15} \mathrm{~N}$ baseline used to determine the TL of consumers is of primary importance. They calculated that the error variance in consumer trophic position was 3 times larger when using primary producers rather than primary consumers as baseline indicator organisms. In this perspective, we considered primary consumers as time (season) integrators of the primary producer isotopic variability, and the primary consumer Haploops nirae that feeds on phytoplankton (Rigolet et al. 2011) was used as the isotopic baseline. As a result, consumer trophic position can be calculated using the following formula:

Trophic level $=$

$$
\left(\delta^{15} \mathrm{~N}_{\text {consumer }}-\delta^{15} \mathrm{~N}_{\text {mean Haploops }}\right) / 3.4+2
$$

where $3.4(\%)$ is the assumed mean ${ }^{15} \mathrm{~N}$ trophicenrichment factor according to Minagawa \& Wada (1984). Primary, secondary and tertiary consumers were thus designated as the second, third and fourth TLs, respectively.

Numerous approaches to solve isotopic mixing models and quantify the relative contributions of primary producers to species' diets have been developed (see review in Layman et al. 2012). Conventional linear mixing models such as IsoError and IsoSource (Phillips \& Gregg 2003, Phillips 2012) calculate the contribution of food resources to a consumer's diet using a set of mass balance equations. However, such mixing models cannot incorporate uncertainties and variations in the isotopic compositions of prey and consumers, and most importantly, the outputs from these models represent a range of feasible solutions, with no quantification as to which solutions are most likely (Parnell et al. 2010). Quite recently, Bayesian mixing models have been proposed to circumvent many limitations of the linear models. They are also based on a set of linear equations that use Bayesian statistical techniques to identify the relative contributions of different sources, but they allow variability in input terms. Furthermore, 
outputs from the Bayesian models are in the form of true probability distributions and not a list of all feasible solutions (Parnell et al. 2010). In the present study, we ran Bayesian mixing models with the Stable Isotope Analysis in R (SIAR) package of the free software R v2.11.1 (R Development Core Team 2010) using default parameters. For a more comprehensive output, the model was performed only on species that account for the greatest part of the benthic biomass (i.e. $80 \%$ ), i.e. 6 species in the Amphiura habitat and 5 species in the Haploops habitat. Biomass data (not presented here) were obtained using grab samples collected in each habitat, from which macrofauna (>1 mm) was identified and weighed (ash-free dry weight). The relative contribution of each species to the total habitat biomass was then calculated and used to select species (C. Rigolet et al. unpubl.). The model was run for summer isotopic compositions only, as it has been shown that mixing model results from the winter period in temperate regions were irrelevant since turnover in organisms' tissues was close to zero (Marín Leal et al. 2008) and food assimilation was ultimately negligible. Two variables $\left(\delta^{13} \mathrm{C}\right.$ and $\delta^{15} \mathrm{~N}$ ) were used and 3 sources (POM, SOM and EPI) were considered for the computation of the model, as a posteriori knowledge of isotopic signature and relative importance of macroalgae and TOM sources were likely too low to be integrated in the mixing model and would otherwise increase uncertainties in model outputs (Fry 2013).

Mixing models require an a priori estimate of the enrichment in $\delta^{15} \mathrm{~N}$ and $\delta^{13} \mathrm{C}$ values between preys and predators. Variations in fractionation values contributed to the major part of the error variance in mixing model outputs (Phillips \& Gregg 2003, Fry 2013).
While it is commonly assumed that the $\delta^{15} \mathrm{~N}$ and the $\delta^{13} \mathrm{C}$ values of a consumer are typically enriched by 3.4 and $1 \%$, respectively (Minagawa \& Wada 1984), recent reviews indicate that fractionation values are affected by multiple factors, such as food quality, tissue turnover, environmental conditions and even taxonomic group (Vander Zanden \& Rasmussen 2001, McCutchan et al. 2003, Vanderklift \& Ponsard 2003). Caut et al. (2009) reviewed carbon and nitrogen isotopic discrimination factors from the literature and suggested linear models to estimate discrimination factors according to the signature of food sources. We calculated a trophic enrichment factor (TEF) for each source following the equations provided by Caut et al. (2009) for invertebrates. We used source-specific TEF for the POM $(4.04 \pm 0.20 \%$ for $\delta^{15} \mathrm{~N}$ and $2.18 \pm 0.11 \%$ or for $\left.\delta^{13} \mathrm{C}\right), \mathrm{SOM}(3.32 \pm 0.12 \%$ for $\delta^{15} \mathrm{~N}$ and $1.68 \pm 0.02 \%$ for $\left.\delta^{13} \mathrm{C}\right)$ and EPI (3.03 \pm $0.05 \%$ for $\delta^{15} \mathrm{~N}$ and $0.05 \pm 0.07 \%$ or for $\delta^{13} \mathrm{C}$ ). For secondary consumers, TEFs were multiplied by the number of TLs between the basal resources and the consumer, as classically used for community approaches (e.g. Phillips 2012, Colombo et al. 2013). Because we used a Bayesian approach, we were able to insert variability (SD) in TEF values as well (Parnell et al. 2010).

\section{RESULTS}

\section{Food sources}

Isotopic ratios of potential OM sources for the 2 transects and the 2 seasons are listed in Table 1 . The $\delta^{13} \mathrm{C}$ of potential food sources were well discrimina-

Table 1. Stable nitrogen and carbon isotope values (\%; mean and SD) of potential organic matter (OM) sources in the Bay of Concarneau during winter and summer. NA indicates that the sources were not sampled, either because the occurrence was very limited (in the case of macroalgae in winter) or because the water level was too low (in the case of riverine outputs in summer)

\begin{tabular}{|c|c|c|c|c|c|c|}
\hline \multirow{2}{*}{ Potential sources for primary consumers } & \multicolumn{3}{|c|}{- Winter -} & \multicolumn{3}{|c|}{ Summer } \\
\hline & $\delta^{15} \mathrm{~N}(\mathrm{SD})$ & $\delta^{13} \mathrm{C}(\mathrm{SD})$ & $\mathrm{n}$ & $\delta^{15} \mathrm{~N}(\mathrm{SD})$ & $\delta^{13} \mathrm{C}(\mathrm{SD})$ & $\mathrm{n}$ \\
\hline Terrestrial OM & $4.05(0.20)$ & $-28.58(0.20)$ & 3 & NA & NA & - \\
\hline Phytoplankton (subsurface seawater) & $3.06(1.20)$ & $-24.06(0.34)$ & 3 & $4.14(1.04)$ & $-23.73(1.08)$ & 3 \\
\hline Sedimented OM (Haploops habitat) & $6.70(0.03)$ & $-21.14(0.04)$ & 3 & $6.60(0.14)$ & $-21.35(0.04)$ & 3 \\
\hline Sedimented OM (Amphiura habitat) & $6.17(0.40)$ & $-21.23(0.21)$ & 3 & $6.08(0.30)$ & $-21.18(0.10)$ & 3 \\
\hline Epiphytes on Haploops tubes & $7.67(0.82)$ & $-21.43(0.36)$ & 3 & $7.21(0.15)$ & $-13.19(0.34)$ & 3 \\
\hline Laminaria sp. (brown macroalgae) & NA & NA & - & $5.07(0.78)$ & $-18.77(2.26)$ & 3 \\
\hline Dictyota dichotoma (brown macroalgae) & NA & NA & - & $5.80(<0.01)$ & $-21.13(<0.01)$ & 3 \\
\hline Palmaria palmata (red macroalgae) & NA & NA & - & $6.09(<0.01)$ & $-33.94(<0.01)$ & 3 \\
\hline Hypoglossum hypoglossoides (red macroalgae) & NA & NA & - & $5.49(<0.01)$ & $-33.35(<0.01)$ & 3 \\
\hline Dasya corymbifera (red macroalgae) & NA & NA & - & $6.85(<0.01)$ & $-34.29(<0.01)$ & 3 \\
\hline Ulva sp. (green macroalgae) & NA & NA & - & $4.18(<0.01)$ & $-17.42(<0.01)$ & 3 \\
\hline
\end{tabular}


ted and varied from $-28.58 \%$ (TOM) to $-21.14 \%$ (SOM) in winter and from $-34.29 \%$ (Dasya corymbifera, a red alga) to $-13.19 \%$ (EPI on Haploops tubes) in summer. The potential food sources displayed a $\delta^{13} \mathrm{C}$ range of $7.4 \%$ in winter, which increased to $21.1 \%$ in summer mainly because of the ${ }^{13} \mathrm{C}$ enrichment of benthic diatoms collected on the Haploops tubes (EPI) and the ${ }^{13} \mathrm{C}$ depletion of benthic red macroalgae (Table 1). Terrestrial input (TOM) $\delta^{13} \mathrm{C}$ values were depleted in ${ }^{13} \mathrm{C}$ in winter $(-28.58 \%$ ) but were not sampled in summer (dry season), when the riverine flow was at its lowest. As for the phytoplankton (POM), $\delta^{13} \mathrm{C}$ values recorded in winter $(-24.06 \%)$ and summer $(-23.73 \%)$ did not differ significantly ( $t$-test, $\mathrm{p}=0.626$ ). The isotopic signature of macroalgae displayed group-specific isotopic ratios $\left(\delta^{13} \mathrm{C}\right)$ with strongly ${ }^{13} \mathrm{C}$-depleted red algae (Palmaria palmata, Hypoglossum hypoglossoides, Dasya corymbifera) and more ${ }^{13} \mathrm{C}$-enriched brown (Laminaria sp., Dictyota dichotoma) and green (Ulva sp.) macroalgae. Isotopic ratios of SOM exhibited the same values between bare sediment stations (sandy mud Amphiura habitat) and muddy Haploops habitat for both seasons ( $t$-test, $p=0.508$ in winter and $p=0.060$ in summer). Therefore, all isotopic values for SOM were averaged into 1 single average isotopic value for SOM. The isotopic signature of Haploops EPI varied significantly among seasons ( $t$-test, $\mathrm{p}<0.001$ ). While it is close to the SOM signature in winter, it was strongly ${ }^{13} \mathrm{C}$-enriched in summer. The $\delta^{15} \mathrm{~N}$ values of potential food sources spanned from 3.06 to $7.67 \%$ in winter and from 4.14 to $7.21 \%$ in summer.

$\mathrm{Chl} a$ and phaeopigment analyses revealed a much higher total content of primary producer pigments in the Haploops habitat than in the adjacent Amphiura habitat irrespective of the season (Table 2). More specifically, even though phaeopigments are about 1 order of magnitude higher than chl $a_{1}$ a significant content of chl a was found in Haploops sediments in winter. The C:N ratio was lower in the Haploops habitat, suggesting a higher quality of the available OM for benthic consumers.

\section{Benthic habitat food web structures}

The $\delta^{13} \mathrm{C}$ and $\delta^{15} \mathrm{~N}$ values displayed by the benthic fauna for the 2 habitats in winter and summer are shown in Fig. 3 (mean isotopic compositions of each species are provided in Table S1 (winter) and Table S2 (summer) in the Supplement at www.intres.com/articles/suppl/m500p025_supp.pdf). Graphically, 3 potential food sources (i.e. SOM, POM and
Table 2. Chl $a$, phaeopigments and sedimented organic matter C:N ratios in sediments of the 2 habitats (Amphiura and Haploops) for the 2 seasons (winter and summer). Mean values $( \pm$ SD) are calculated for the 3 stations in each habitat

\begin{tabular}{|lcrc|}
\hline & $\begin{array}{c}\text { Chl a } \\
\left(\mu \mathrm{g} \mathrm{g}^{-1}\right)\end{array}$ & $\begin{array}{c}\text { Phaeopigments } \\
\left(\mu \mathrm{g} \mathrm{g}^{-1}\right)\end{array}$ & C:N ratio \\
\hline Winter & & & \\
Amphiura & $0.22( \pm 0.15)$ & $8.74( \pm 2.85)$ & $7.12( \pm 0.58)$ \\
Haploops & $1.06( \pm 0.44)$ & $26.25( \pm 4.48)$ & $5.90( \pm 0.17)$ \\
Summer & & & \\
Amphiura & $1.67( \pm 0.24)$ & $7.99( \pm 3.70)$ & $7.36( \pm 0.71)$ \\
Haploops & $2.04( \pm 0.11)$ & $18.03( \pm 2.14)$ & $5.76( \pm 0.17)$ \\
\hline
\end{tabular}

EPI) are likely to support the primary consumers in the 2 communities. A few species showed particular isotopic signatures. In winter, the sea slug Aplysia punctata (Fig. 3A) displayed highly ${ }^{13} \mathrm{C}$-depleted values $(-29.41$ and $-30.81 \%$ in both Amphiura and Haploops habitats) and appeared to rely on ${ }^{13} \mathrm{C}$ depleted red macroalgae (such as Palmaria palmata, Hypoglossum hypoglossoides and Dasya corymbifera). The polychaete Nereis sp. $\left(\delta^{13} \mathrm{C}=-24.71 \%\right.$ ) also seemed to partly feed on ${ }^{13} \mathrm{C}$-depleted red macroalgae. In summer, the nudibranch Geitodoris planata displayed ${ }^{13} \mathrm{C}$-enriched values (Fig. 3B) in both habitats $\left(\delta^{13} \mathrm{C}=-11.83\right.$ and $-11.64 \%$ in Amphiura and Haploops habitat, respectively). The bivalve Thyasira flexuosa (not plotted in Fig. 3) displayed strongly depleted $\delta^{13} \mathrm{C}(-26.40 \%)$ and $\delta^{15} \mathrm{~N}$ values $(-0.3 \%)$.

The absolute frequencies of $\delta^{13} \mathrm{C}$ and $\delta^{15} \mathrm{~N}$ compositions displayed by all sampled species in the 2 habitats in winter and summer are represented in Fig. 4. Apart from a few species with particular isotopic values (namely Aplysia punctata, Nereis sp., Thyasira flexuosa and Geitodoris planata), the frequency distributions exhibited a similar range in $\delta^{13} \mathrm{C}$ values, with winter compositions spanning from -21.63 (Psammechinus miliaris) to $-14.75 \%$ (Aphrodita aculeata) in the Amphiura habitat and from -20.48 (Schistomeringos rudolphii) to $-14.86 \%$ (Buccinum undatum) in the Haploops habitat. In summer, $\delta^{13} \mathrm{C}$ isotopic values displayed the same pattern, with values ranging from -20.91 (Ampelisca spinipes) to $-13.98 \%$ (Philine aperta) in the Amphiura habitat and from -20.43 (Ampelisca typica) to $-14.26 \%$ (Luidia ciliaris) in the Haploops habitat. Frequency distributions of $\delta^{15} \mathrm{~N}$ values exhibited close variations in the 2 habitats as well, ranging from 7.17 (Ampharete finmarchica) to $14.43 \%$ (Glycera unicornis) in winter in the Amphiura habitat and from 7.02 (Haploops nirae) to $13.28 \%$ (Maja squinado) in the Haploops 

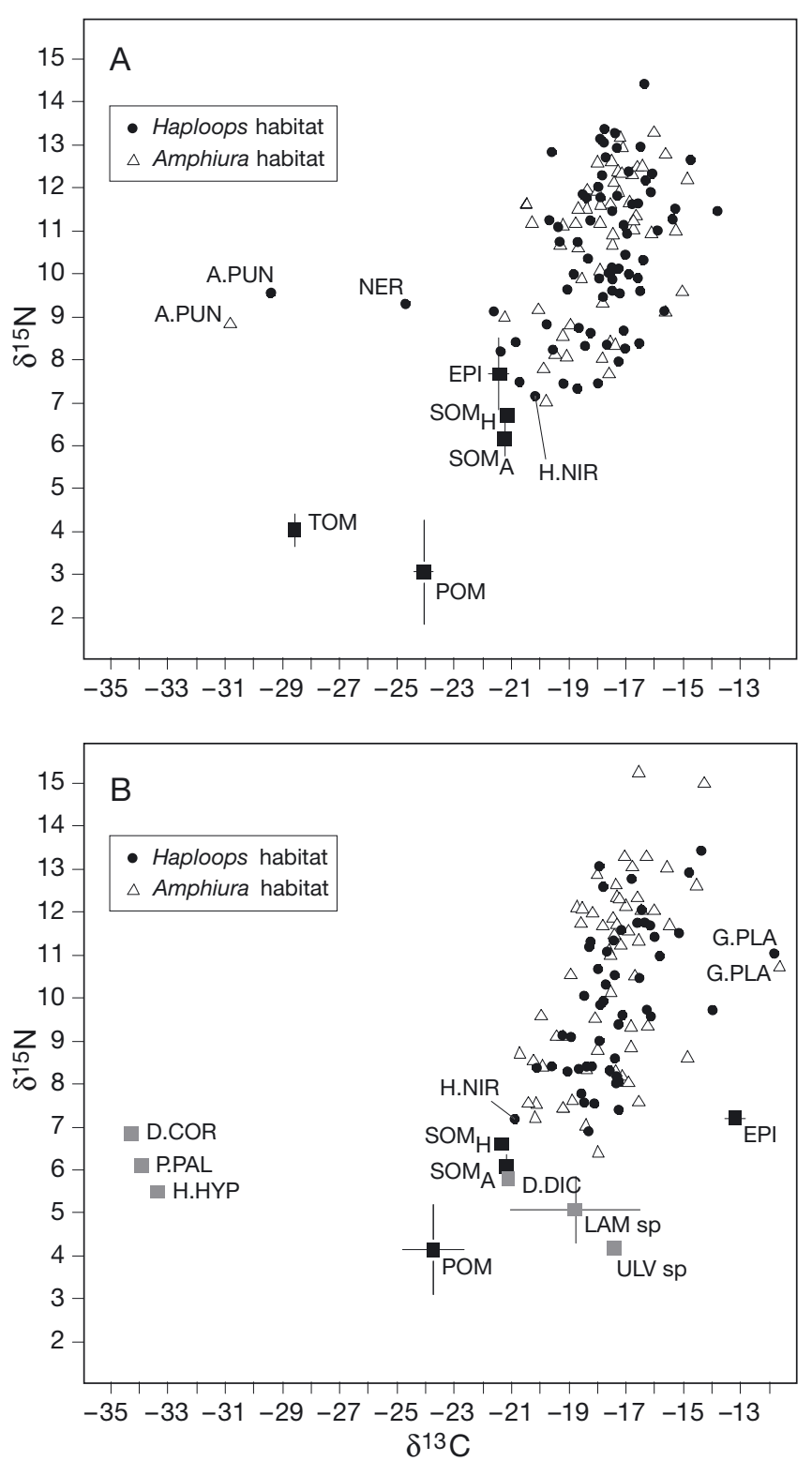

Fig. 3. Carbon and nitrogen isotopic composition $\left(\delta^{13} \mathrm{C}\right.$ and $\delta^{15} \mathrm{~N}$ ) of the sampled species and potential dietary organic matter sources during (A) winter and (B) summer in the sandy mud Amphiura habitat and in the muddy Haploops habitat. Mean isotope compositions $(n=3)$ of all species are plotted. Sources are represented with squares. For benthic consumers' isotopic compositions, mean $\delta^{13} \mathrm{C}$ and $\delta^{15} \mathrm{~N}$ values are represented without error bars for clarity. Thyasira flexuosa $\left(\delta^{15} \mathrm{~N}=-0.30 \pm 0.46 ; \delta^{13} \mathrm{C}=-26.40 \pm 0.29\right)$ was not represented on this graphic. A.PUN $=$ Aplysia punctata, D.COR $=$ Dasya corymbifera, D.DIC $=$ Dictyota dichotoma, EPI = epiphytes scraped from Haploops tubes, G.PLA = Geitodoris planata, H.HYP = Hypoglossum hypoglossoides, H.NIR = Haploops nirae, LAM sp = Laminaria sp., NER = Nereis sp., POM = particulate organic matter, P.PAL $=$ Palmaria palmata, $\mathrm{SOM}_{\mathrm{A}}=$ sedimented organic matter from the Amphiura habitat, $\mathrm{SOM}_{\mathrm{H}}=$ sedimented organic matter from the Haploops habitat, TOM = terrestrial organic matter inputs, ULV sp = Ulva sp. habitat. In summer, $\delta^{15} \mathrm{~N}$ values showed almost identical variations, with $\delta^{15} \mathrm{~N}$ values ranging from 6.93 (Cultellus pellucidus) to $13.45 \%$ (Luidia ciliaris) in the Amphiura habitat and from 6.40 (Timoclea ovata) to $15.24 \%$ (Glycera unicornis) in the Haploops community. The distributions of $\delta^{15} \mathrm{~N}$ values appeared to be bimodal in winter and summer for the Haploops habitat but less structured for the Amphiura habitat. As for the distributions of $\delta^{13} \mathrm{C}$ values, calculations of the Kurtosis index revealed a decrease between winter and summer for the 2 habitats ( 7.4 to 4.1 for the Amphiura habitat and 3.4 to 3.3 for the Haploops habitat), indicating a sign of flattening in the distribution between the 2 seasons. This was most noticeable for the Amphiura habitat, though (Fig. 4).

When pooled into trophic functional groups, organisms' isotopic signatures revealed that the 2 habitats have very similar trophic structures. Indeed, the average values of both $\delta^{13} \mathrm{C}$ and $\delta^{15} \mathrm{~N}$ for each trophic group did not show significant differences between the 2 communities (MANOVA, $p>0.05$ ), irrespective of the season. Trophic groups are characterized by large within-group variations in $\delta^{13} \mathrm{C}$ values (Table 3). Suspension feeders spanned consistently over the same ranges in $\delta^{13} \mathrm{C}$ values (4.44 to $4.85 \%$ ), not only between the 2 seasons but also between the 2 communities. For the 2 seasons and the 2 communities, carnivores-omnivores had the same mean $\delta^{13} \mathrm{C}$ range ( 4.47 to $4.87 \%$ ), except in the Haploops habitat in winter, where carnivores-omnivores exhibited a larger $\delta^{13} \mathrm{C}$ range (i.e. 6.38\%o). Unlike other trophic groups, surface deposit feeders had no clear pattern in $\delta^{13} \mathrm{C}$ ranges and varied from 1.82 up to $4.51 \%$. The Haploops community is characterized for both seasons by a narrower $\delta^{13} \mathrm{C}$ range in subsurface deposit feeders (mean $1.25 \%$ ) compared to the bare sediment community (mean $3.64 \%$ ). Variations in $\delta^{15} \mathrm{~N}$ among trophic groups showed that values for subsurface deposit feeders are consistently above $\mathrm{TL}=3$ and largely overlapping with carnivores-omnivores. The largest community variation is because of surface deposit feeders in winter exhibiting higher $\delta^{15} \mathrm{~N}$ values in the Haploops habitat (TL $>3$ ) than in the Amphiura habitat $(\mathrm{TL}<3)$.

\section{Comparison of isotopic values of species shared by the 2 communities}

A total of $28(36 \%)$ and $17(18 \%)$ species were found in both habitats in winter and summer, respectively. Stable isotope ratios of common species of the 2 habitats are represented in the same biplots 

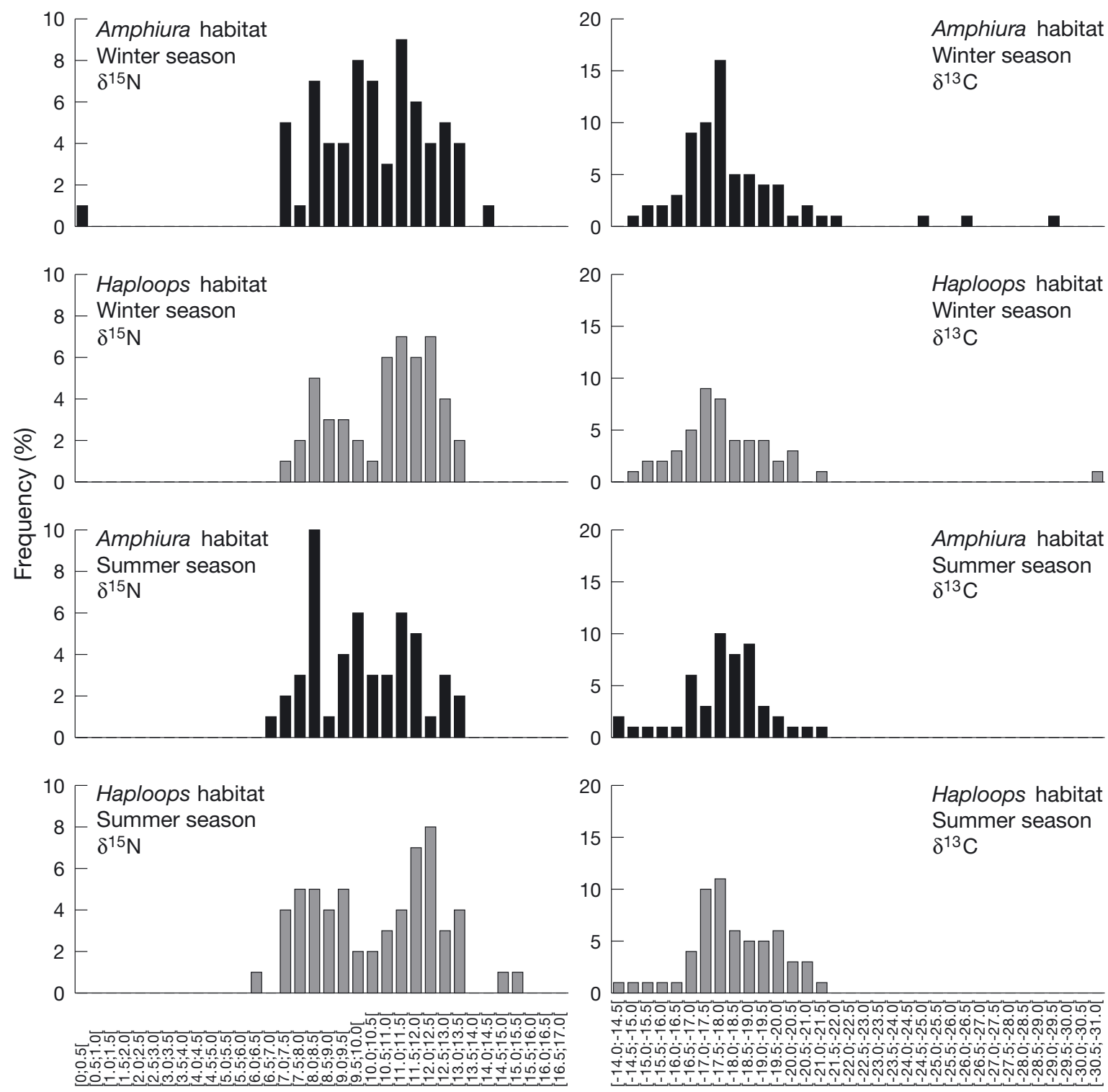

Fig. 4. Frequency distributions of carbon and nitrogen isotopic compositions of all organisms sampled in the 2 habitats (Amphiura and Haploops) for the 2 seasons (winter, summer). A size class of $0.5 \%$ was used for both elements

Table 3. Ranges in carbon isotope values $\left(\delta^{13} \mathrm{C}\right)$ (minimum; maximum, \%) for each trophic functional group found in the 2 habitats (Amphiura and Haploops) for the 2 seasons (winter and summer). Because of specific and unique diets (see Fig. 3),

Thyasira flexuosa, Aplysia punctata and Nereis sp. were excluded from the calculations. $\mathrm{n}=$ number of species

\begin{tabular}{|c|c|c|c|c|c|c|c|c|}
\hline \multirow{2}{*}{ Habitat } & \multicolumn{4}{|c|}{ - Winter } & & \multicolumn{3}{|c|}{ - Summer } \\
\hline & Amphiura & $\mathrm{n}$ & Haploops & $\mathrm{n}$ & Amphiura & $\mathrm{n}$ & Haploops & $\mathrm{n}$ \\
\hline Carnivores-omnivores & $\begin{array}{c}4.87 \\
(-19.62 ;-14.75)\end{array}$ & 35 & $\begin{array}{c}6.38 \\
(-21.24 ;-14.86)\end{array}$ & 27 & $\begin{array}{c}4.51 \\
(-18.49 ;-13.98)\end{array}$ & 15 & $\begin{array}{c}4.93 \\
(-19.19 ;-14.26)\end{array}$ & 23 \\
\hline Subsurface deposit feeders & $\begin{array}{c}4.11 \\
(-19.39 ;-15.28)\end{array}$ & 9 & $\begin{array}{c}1.68 \\
(-18.42 ;-16.74)\end{array}$ & 5 & $\begin{array}{c}3.17 \\
(-18.33 ;-15.16)\end{array}$ & 8 & $\begin{array}{c}0.87 \\
(-18.18 ;-17.31)\end{array}$ & 6 \\
\hline Surface deposit feeders & $\begin{array}{c}4.51 \\
(-20.18 ;-15.67)\end{array}$ & 7 & $\begin{array}{c}3.64 \\
(-18.67 ;-15.03)\end{array}$ & 5 & $\begin{array}{c}1.82 \\
(-18.38 ;-16.56)\end{array}$ & 5 & $\begin{array}{c}3.28 \\
(-19.97 ;-16.69)\end{array}$ & 9 \\
\hline Suspension feeders & $\begin{array}{c}4.85 \\
(-21.42 ;-16.57)\end{array}$ & 19 & $\begin{array}{c}4.44 \\
(-20.07 ;-15.63)\end{array}$ & 12 & $\begin{array}{c}4.74 \\
(-20.91 ;-16.17)\end{array}$ & 19 & $\begin{array}{c}4.45 \\
(-20.71 ;-16.26)\end{array}$ & 20 \\
\hline
\end{tabular}



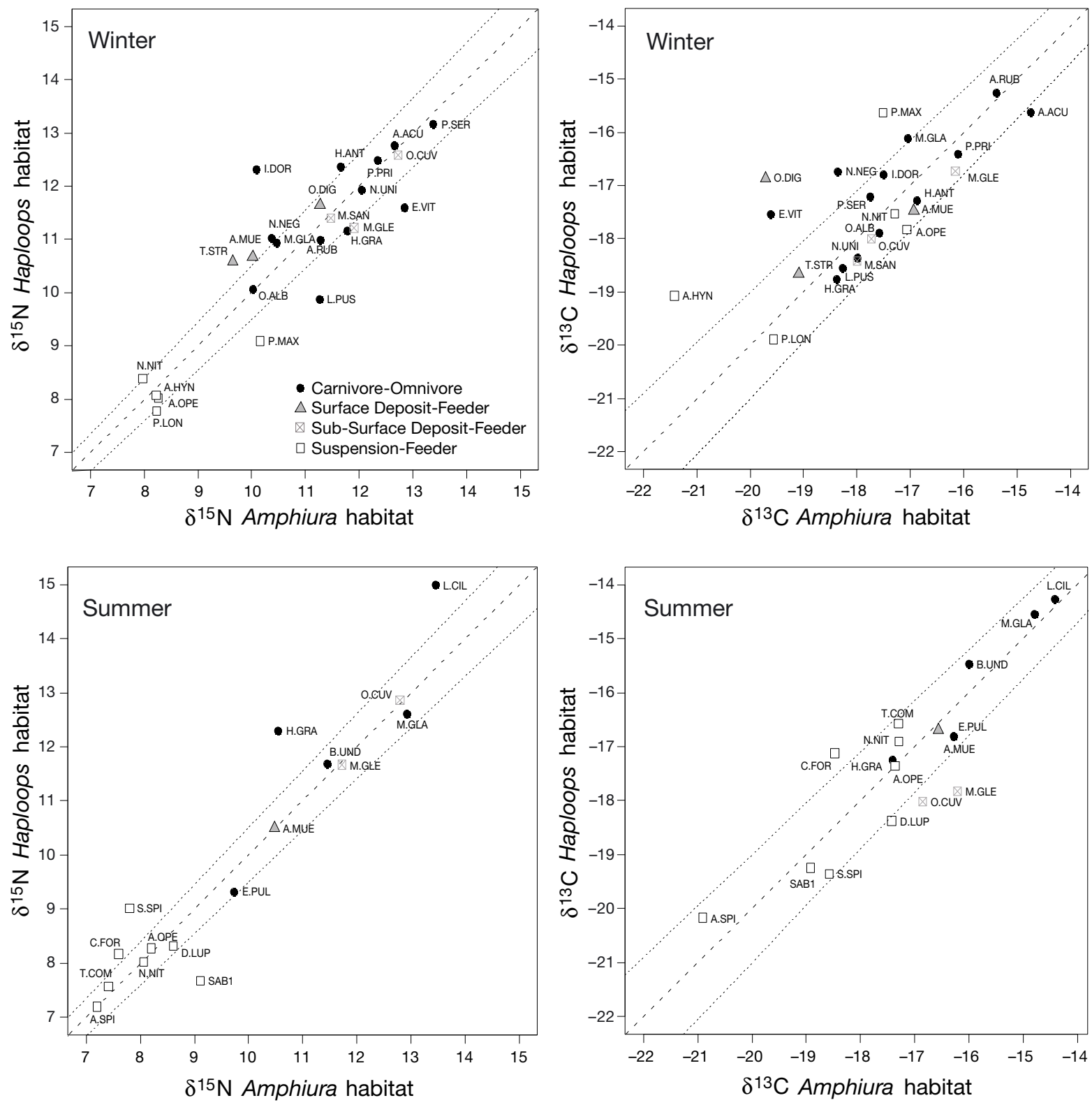

Fig. 5. Comparison of nitrogen and carbon isotope composition $\left(\delta^{15} \mathrm{~N}\right.$ and $\left.\delta^{13} \mathrm{C}\right)$ of species co-occurring in both the Amphiura and the Haploops habitats in winter and summer. Dashed line indicates a 1:1 correlation (95\% confidence interval in light dotted lines); species on the 1:1 line indicates no significant differences in isotopic composition between the 2 habitats. Species labels are coded according to their trophic group. A.ACU $=$ Aphrodita aculeata, A.HYN = Anapagurus hyndmanni, A.MUE $=$ Aspidosiphon muelleri, A.OPE $=$ Aequipecten opercularis, A.RUB $=$ Asterias rubens, A.SPI $=$ Ampelisca spinipes, B.UND $=$ Buccinum undatum, C.FOR = Crepidula fornicata, D.LUP = Dosinia lupines, E.PUL = Euspira pulchella, E.VIT $=$ Eunice vitata, H.ANT = Harmothoe antilopes, H.GRA = Hilbigneris gracilis, I.DOR = Inachus dorsettensis, L.CIL = Luidia ciliaris, L.PUS = Liocarcinus pusillus, M.GLA = Martasterias glacialis, M.GLE = Maldane glebifex, M.SAN = Macroclymene santanderansis, N.NEG = Natatolana neglecta, N.NIT = Nucula nitidosa, N.UNI = Nematonereis unicornis, O.ALB = Ophiura albida, O.CUV $=$ Orbinia cuvierii, O.DIG = Oestergrenia digitata, P.LON = Pisidia longicornis, P.MAX = Pecten maximus, P.PRI = Pagurus prideaux, $\mathrm{P} . \mathrm{SER}=$ Palaemon serratus, $\mathrm{SAB} 1=$ Sabellidae $\mathrm{sp}$. undetermined, $\mathrm{S} . \mathrm{SPI}=$ Sabellaria spinulosa, $\mathrm{T} . \mathrm{COM}=$ Turritella communis, T.STR $=$ Terebellides stroemii

(Fig. 5). Overall, the majority of species fall within the range of the 1:1 ratio for the 2 seasons. However, some species exhibited isotopic differences between the 2 habitats. For example, in winter the $\delta^{15} \mathrm{~N}$ values of the predators Eunice vittata and Liocarcinus pusillus and the suspension feeder Pecten maximus were lower in the Haploops habitat. Conversely, the predator Inachus dorsettensis and the surface deposit 

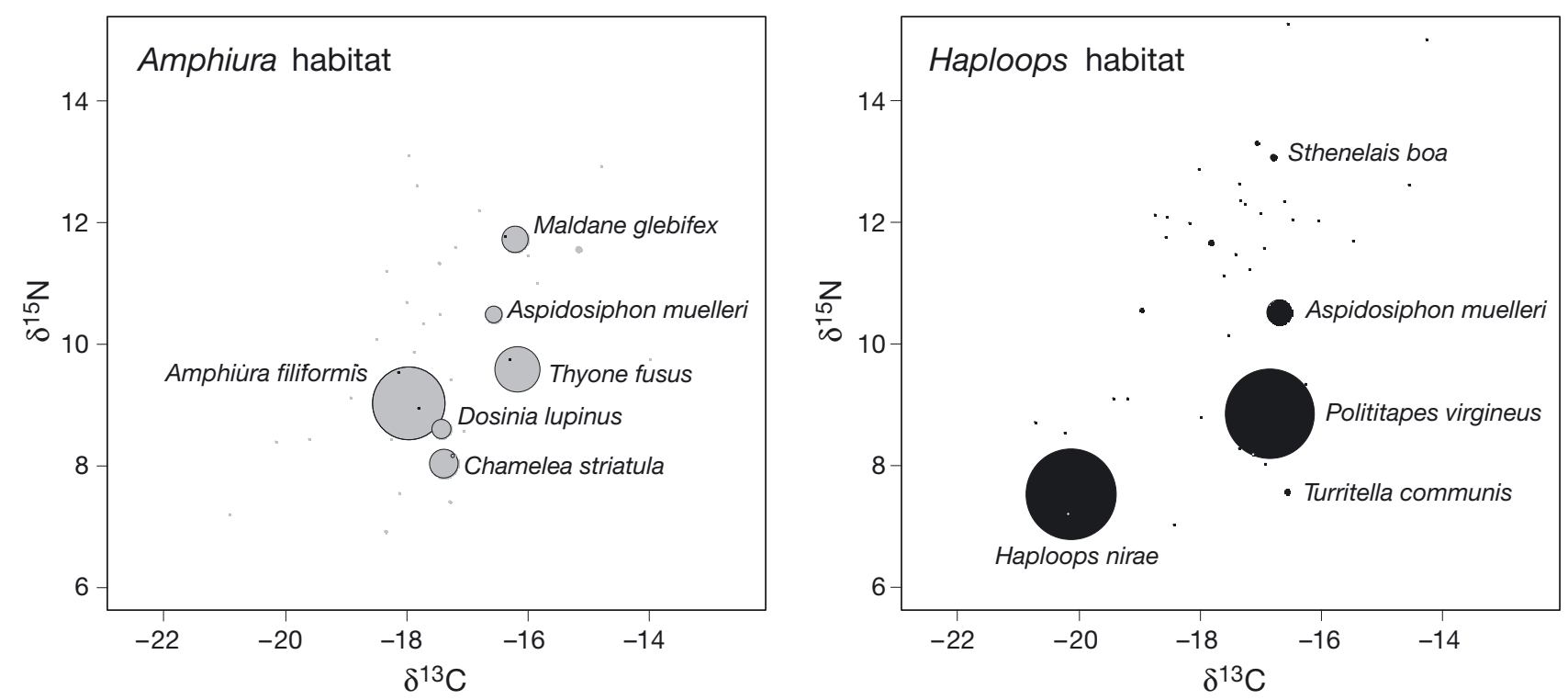

Fig. 6. Dual isotopic carbon vs. nitrogen $\left(\delta^{13} \mathrm{C}\right.$ vs. $\left.\delta^{15} \mathrm{~N}\right)$ biplot of species collected in the 2 habitats in summer. Bubble values represent relative contribution of each species to the total biomass of each habitat. Species representing $80 \%$ of the total biomass are labelled

feeder Terebellides stroemi exhibited higher $\delta^{15} \mathrm{~N}$ values in the Haploops habitat. As for winter $\delta^{13} \mathrm{C}$ values, common species tend to be ${ }^{13} \mathrm{C}$-enriched in the Haploops habitat, as evidenced by the 2 suspension feeders Pecten maximus and Anapagurus hyndmanni as well as the deposit feeder Oestergrenia digitata and the predators Eunice vittata and Natatolana neglecta. The same pattern is observed in summer. Several species showed enriched $\delta^{15} \mathrm{~N}$ values in the Haploops habitat (Scoletoma fragilis and Sabellaria spinulosa) while others are ${ }^{15} \mathrm{~N}$-depleted (Sabellidae sp.). As for summer $\delta^{13} \mathrm{C}$ values, subsurface deposit feeders (Orbinia cuvieri and Maldane glebifex) were ${ }^{13} \mathrm{C}$-depleted in the Haploops habitat, while the suspension feeder Crepidula fornicata displayed slightly enriched $\delta^{13} \mathrm{C}$ values in the Haploops habitat.

\section{Contribution of food sources to benthic food webs}

Biomass data revealed that 5 and 6 species accounted for more than $80 \%$ of the benthic fauna biomass in summer in the Haploops and Amphiura habitats, respectively. When plotted along with isotopic compositions, biomass revealed a completely different picture of the food web for each habitat (Fig. 6). In the Amphiura habitat, the suspension feeders Amphiura filiformis, Thyone fusus, Dosinia lupinus and Chamelea striatula made up for the bulk of the benthic biomass. The subsurface deposit feeder Maldane glebifex and the surface deposit feeder Aspidosiphon muelleri accounted to a lesser extent for the biomass in this habitat. In the Haploops habitat, the amphipod Haploops nirae and the bivalve Polititapes virgineus each accounted for $35 \%$ of the biomass of the benthic fauna. The other main suspension feeder, Turritella communis, as well as the surface deposit feeder Aspidosiphon muelleri and the predator Sthenelais boa accounted for the remaining benthic biomass in the Haploops habitat.

Boxplots showing results of the Bayesian mixing models computed on species that accounted for $80 \%$ of the biomass in summer are shown in Fig. 7. Overall, the 2 communities exhibited similar patterns in food source contributions. Even though large uncertainties hampered accurate quantifications, epiphytes (represented by benthic diatoms Navicula sp.) seemed to be the largest contributors, with the smallest uncertainties for most suspension feeders. The phytoplankton contribution (POM), however, is associated with large, $95 \%$ confidence intervals but also significantly contributes to suspension feeders' diets such as Haploops nirae in the Haploops habitat or Dosinia lupinus and Chamelea striatula in the Amphiura habitat. The predator Sthenelais boa seemed to feed primarily on organisms which feed primarily on POM. The contribution of OM from the sediment seemed to be less obvious from SIAR outputs, as it is also associated with large uncertainties. 


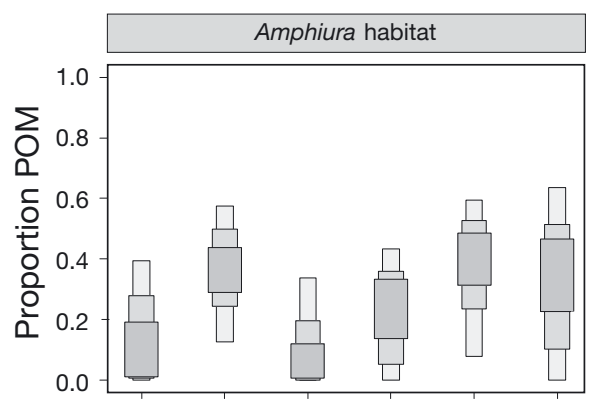

M.GLE A.FIL A.MUE T.FUS D.LUP C.STR

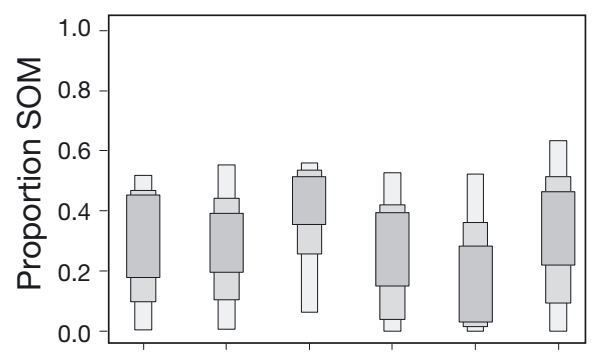

M.GLE A.FIL A.MUE T.FUS D.LUP C.STR

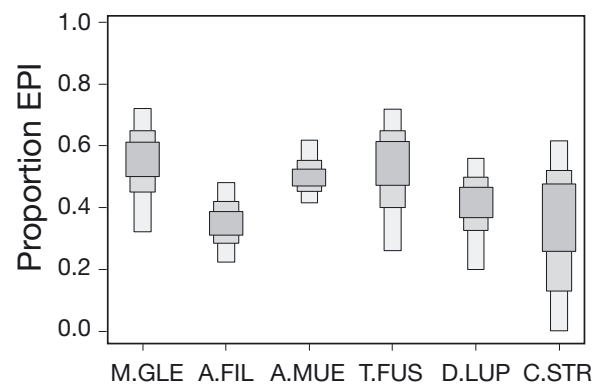

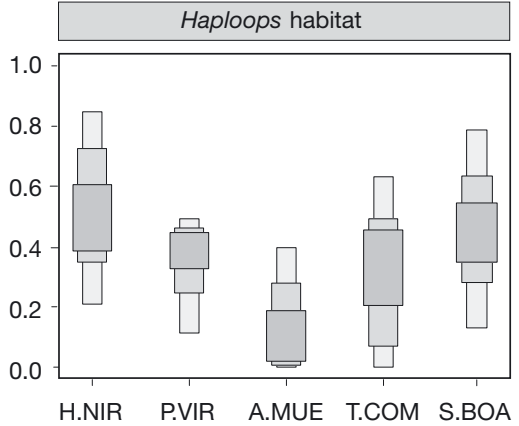
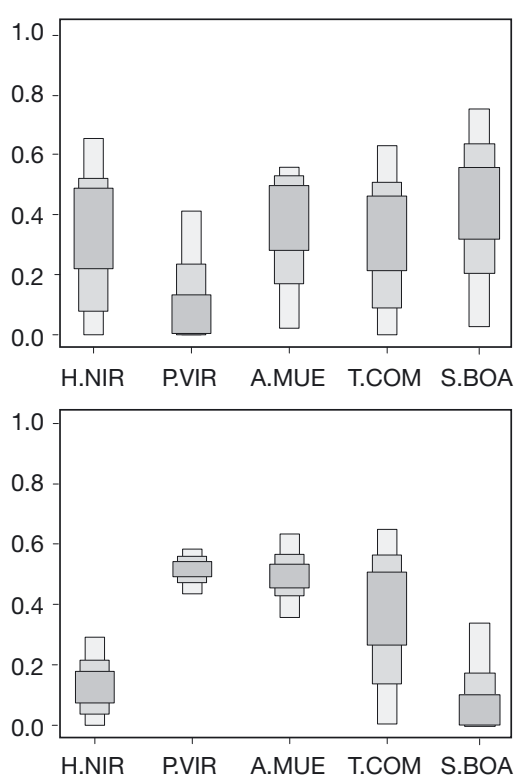

Fig. 7. Estimated contributions of the 3 main food sources, particulate organic matter (POM), sedimented organic matter (SOM) and tube epiphytes (EPI), for the Amphiura and the Haploops habitats in summer using the Stable Isotope Analysis in R mixing model. Boxplots indicate 50, 75 and $95 \%$ confidence intervals for the species that account for $80 \%$ of the biomass in each habitat: A.FIL $=$ Amphiura filiformis, A.MUE $=$ Aspidosiphon muelleri, C.STR $=$ Chamelea striat ula, D.LUP = Dosinia lupinus, H.NIR = Haploops nirae, M.GLE = Maldane glebifex, $\mathrm{P} . \mathrm{VIR}=$ Polititapes virgineus, $\mathrm{S} . \mathrm{BOA}=$ Sthenelais boa, $\mathrm{T} . \mathrm{COM}=$ Turritella communis, T.FUS $=$ Thyone fusus

\section{DISCUSSION}

In shallow subtidal zones, amphipod populations are common and can generate extensive tube mats that considerably increase local habitat complexity (Franz \& Tanacredi 1992, Göransson 2002). Engineer species in general and tubicolous species in particular are known to affect species composition of softbottom communities (Reise et al. 2009). Rigolet et al. (2014) showed that the presence of Haploops nirae in the Bay of Concarneau (southern Brittany) affects the local biodiversity and associated species assemblages. By modifying local sedimentary features, Haploops individuals create conditions for an un- usual species assemblage to settle and develop, with species found only within the Haploops community, including species new to science (Myers et al. 2012). To investigate whether drastic changes in species composition also cause changes in food web structure, we sampled the diversity of benthic organisms associated with the Haploops habitat and the adjacent uncolonized Amphiura habitat over 2 seasons.

Our results first showed that the overall isotopic food web structure was similar between the 2 habitats, since the isotopic spaces occupied by the species in the $\delta^{13} \mathrm{C}-\delta^{15} \mathrm{~N}$ biplots largely overlap. The distribution of species over a continuum of 3 TLs appears to be a common feature in temperate subtidal macrobenthic ecosystems. Indeed, Le Loc'h et al. (2008) for the muddy Nephrops habitat in the Bay of Biscay, Grall et al. (2006) for the northeastern Atlantic maerl bed habitat or Carlier et al. (2007) for a variety of soft-sediment habitats of the northwestern Mediterranean Bay of Banyuls also reported food web structures of benthic macrofauna with 3 TLs. We also showed here that isotopic values for both primary and secondary consumers spread over a large range of $\delta^{13} \mathrm{C}$ values. Such a large range of $\delta^{13} \mathrm{C}$ values within primary consumers is also considered a common feature of continental shelf communities (Hobson et al. 2002, Le Loc'h et al. 2008), where a larger number of food sources are available. And yet, the $\delta^{13} \mathrm{C}$ ranges for subtidal shallow benthic habitats seem to remain stable between -14 and $-22 \%$ for the whole macrofauna community (Grall et al. 2006, Carlier et al. 2007, Le Loc'h et al. 2008). However, we have excluded species exhibiting unusual isotopic signatures from very specific diets, e.g. specialists of very ${ }^{13} \mathrm{C}$-depleted red macroalgae such as Aplysia punctata (Carefoot 1987) or species which host symbiotic sulphur-oxidizing bacteria in their gill tissue such as Thyasira flexuosa (Dufour \& Felbeck 2006). This depletion is likely because of the significant contribution of carbon fixation by symbionts in their food source (Dando \& 
Spiro 1993). It should be noted that between-habitat variations in organisms' isotopic compositions are not only caused by intraspecific trophic plasticity but are likely to be constrained within food sources' isotopic compositions at the ecosystem level.

Several studies reported that Ampeliscidae can constitute the major prey for some top predators, marine mammals and finfishes (Franz \& Tanacredi 1992, Highsmith \& Coyle 1992, Cui et al. 2012). To our knowledge, few studies have paid special attention to the position of the Ampeliscidae in a food web, and even fewer use stable isotopes to ascertain this. Haploops nirae occupied here the lowest $\delta^{13} \mathrm{C}$ and $\delta^{15} \mathrm{~N}$ positions in the isotopic biplot. Ampeliscidae always exhibit the lowest $\delta^{15} \mathrm{~N}$ value in food web structures determined with stable isotopes, as shown from the muddy bottoms of the southern Tyrrhenian Sea (western Mediterranean) for Ampelisca spp. (Fanelli et al. 2009) to the South Orkney Islands (Antarctic Peninsula) for A. richardsoni (Nyssen et al. 2005). We suggest here that this amphipod family in general, despite laboratory observations reporting strong trophic plasticity and changes in foraging behaviour (e.g. Mills 1967), can be used as an isotopic trophic baseline for coastal marine and estuarine systems. This provides a viable alternative to the current practice of using long-lived primary consumers like mussels as a trophic baseline (Cabana \& Rasmussen 1996).

Despite the strong bioturbating tube-building activity (over 10000 tubes $\mathrm{m}^{-2}$, Rigolet et al. 2012) and active grazing activity (Rigolet et al. 2011), Haploops individuals do not appear to affect the higher TLs. As suggested by Mills et al. (1993), the feeding activities of dense species greatly affect community features (such as sediment characteristics) but do not necessarily have direct trophic effects on other species. Similarly, Jones et al. (1994) suggested that many engineer species physically affect their environment in numerous ways but that not all of the changes have important (positive or negative) ecological consequences. Studies that compare food webs of engineered habitat with adjacent homogeneous bare sediments using stable isotopes are scarce (but see for example Dubois et al. 2007). Yet, Baeta et al. (2009) investigated whether the occurrence of the eelgrass Zostera marina changed the benthic and pelagic food web structures in comparison with uncolonized sediment. They showed no major difference in the structure of the benthic food web, which is consistent with our results in a different system. This result has strong implications in terms of trophic niche partitioning; as composition of species assemblages associated with Haploops habitat drastically differs from those in adjacent sediments (Rigolet et al. 2014), it means that each species or each group of species uniquely found in the Haploops habitat (ca. $70 \%$ of the species) has a trophically equivalent species or group of species in the adjacent uncolonized sediments. As a result, deep changes in diversity and species composition do not always reflect changes in food web structure, even though the physical environment is remarkably affected by an engineer tubicolous species.

As measured with the $\delta^{15} \mathrm{~N}$ ranges, the length of the benthic food chain in the Haploops habitat did not differ from the length in the adjacent Amphiura habitat. Both food chains spanned over a continuum of almost 3 TLs, defined according to an isotopic baseline (Post 2002). Food web length in aquatic systems influences ecosystem functioning and food web stability (Long et al. 2011), but it is also recognized that longer food webs are predicted in more productive systems because more energy can be transferred between TLs (Morin \& Lawler 1995). Secondary production is not significantly different between Haploops habitats and surrounding Amphiura habitats (Rigolet et al. 2012), further suggesting that a difference in food chain length would be unlikely. However, it is worth noticing differences in the frequency distributions of $\delta^{15} \mathrm{~N}$ compositions between the Amphiura and the Haploops habitats. The bimodal shape of the distribution of the Haploops habitat revealed that food chain levels between primary and secondary consumers are well discriminated in Haploops habitat, possibly indicating less trophic plasticity and fewer diet variations at each consumer level, and that more omnivorous species are present in the Amphiura habitat, with potential consequences on the food web properties of each habitat. The influence of complexity and omnivory on food web dynamics was intensively debated during the last decades, with contradictory results. Recent empirical and theoretical developments have shown that omnivory in general and omnivorous links between species tend to have a stabilizing effect on food web dynamics when trophic interactions are weak (Emmerson \& Yearsley 2004). With this in mind, we could hypothesize that the Haploops food web, largely dominated in terms of abundance and biomass by a gregarious small tubicolous species, is less stable than the Amphiura food web and would ultimately take more time to return to equilibrium should large changes in food sources occur.

In coastal shallow systems, the biomass and the secondary production of benthic consumers originate 
from a diversity of sources (Peterson 1999). For example, in the Bay of Concarneau, many sources are potentially available for the benthic fauna, such as POM, SOM and TOM as well as macroalgae detritus from surrounding hard bottoms. It is commonly assumed that the subsurface POM (used as a proxy for phytoplankton) directly or indirectly (after sedimentation and resuspension) is the major contribution to benthic primary consumers in subtidal environments (Grall et al. 2006, Le Loc'h et al. 2008). However, a growing body of literature recently focused on subtidal benthic primary production in subtidal sedimentary habitats (see review in Cahoon 1999). For example, Grippo et al. (2011) investigated the MPB as a potential supporter of the benthic food web in Louisiana shoals (Gulf of Mexico) and revealed that subtidal sandy dunes (peaking between 5 and $10 \mathrm{~m}$ depth) are supporting a secondary benthic production during spring and summer. In temperate shallow subtidal sedimentary systems of the Wadden Sea (ca. $2 \mathrm{~m}$ depth), ${ }^{13} \mathrm{C}$-labelling in situ experiences revealed the pivotal role of autochthonous MPB production vs. allochthonous phytoplankton in benthic consumers' diets (Evrard et al. 2012), and within the bulk MPB, benthic consumers preferentially select benthic diatoms and benthic cyanobacteria (Evrard et al. 2010). An extensive survey of subtidal MPB production was carried out in the Bay of Brest (Brittany, France) between 5 and 13 m deep (Ní Longphuirt et al. 2007). These authors highlighted that MPB production represented up to $20 \%$ of total primary production, with the highest MPB biomass in bare muddy sediments. Our results from sediment analyses showed that even during the winter season, and despite a higher turbidity because of wave activity, Haploops sediment contains chl a. This probably indicates benthic primary production in Haploops sediments, supported by a low C:N ratio close to what was expected for marine microalgae (i.e. $\mathrm{C}: \mathrm{N}=6.6$; Redfield et al. 1963). Visual observations showed that Haploops tubes can be a physical support for epiphytes in general and benthic diatom mats in particular (Navicula sp.) (Fig. 2). The $\delta^{13} \mathrm{C}$ value from the tube EPI falls perfectly within the expected value of MPB in summer (ca. $-13 \%$ ) (Riera \& Richard 1996, Marín Leal et al. 2008, Grippo et al. 2011). However, in winter (higher turbidity and lower luminosity), tube scrapings revealed a $\delta^{13} \mathrm{C}$ value similar to the SOM, suggesting an absence of growing mats of primary producers on Haploops tubes. Yet a low chl a concentration indicates a residual growing population of microalgae. Haploops tubes are made of mud, with pseudofaeces and mucus secreted by individuals (Rigolet et al. 2011), and potentially offer a high-quality habitat of polysaccharides for benthic diatoms to grow. Benthic diatoms (including Navicula species) can compensate for low nutrients or luminosity with adaptations such as mixotrophy (Cloern \& Dufford 2005, Ross \& Sharples 2007). For example, Barillé \& Cognie (2000) showed that growth of benthic diatoms was stimulated by oyster pseudofaeces, enriching sediment in mucopolysaccharides which diatoms can exploit. Carbohydrates derived from Haploops tubes can likely be used by diatoms to grow under limited light condition.

SIAR Bayesian mixing models incorporate isotope and fractionation uncertainty in the development of posterior probability distributions of source contributions. As a result, model outputs include a margin of error that can be high when too many food sources are incorporated or when consumers' isotopic compositions do not fall perfectly within the isotopic space defined by selected food sources (Fry 2013). Since SOM and POM are not isotopically well discriminated in this study, results of the mixing model are associated with high uncertainty for those 2 food sources. EPI (benthic diatoms) exhibited very significantly enriched $\delta^{13} \mathrm{C}$ values $(-13.19 \pm 0.34 \%)$, and their contribution to the diet to the species with the most enriched $\delta^{13} \mathrm{C}$ values is undoubted. The species with the highest $\delta^{13} \mathrm{C}$ value $(-11.64 \pm 0.2 \%)$ is indeed the micrograzer Geitodoris planata, likely feeding solely on the EPI of Haploops tubes. Also, many species can benefit from this food source, especially deposit feeders which indeed are more abundant in the Haploops habitat (Rigolet et al. 2014) or suspension-feeding species if benthic diatoms are resuspended. Interestingly, while investigating isotopic signatures of benthic invertebrates in a coastalestuarine gradient, Kopp et al. (2013) noticed an unexpected enrichment in organisms' $\delta^{13} \mathrm{C}$ isotopic composition only in several offshore stations (Bay of Biscay, France). These stations were actually colonized by Haploops sp., and our findings suggest a contribution of MPB to the macrofauna diet.

Our understanding of food web structure can be very different depending on whether one considers all the species or only the species that account for most of the biomass. Those species play a key functional role in trophic webs (Villéger et al. 2008). From the species contributing the most to the total biomass in each community, Bayesian mixing models revealed that EPI can contribute up to $50 \%$ to the diet of suspension feeders such as Polititapes virgineus or Amphiura filiformis, while other suspension feeders 
rely mainly on POM (Haploops nirae), suggesting differences in food selectivity among filter-feeding organisms but also a limited competition within the suspension feeders among the Haploops habitat. The bivalve $P$. virgineus is only found in Haploops habitat and represents one of the largest biomass compartments. MacKenzie et al. (2006) similarly reported high biomass of bivalves Mercenaria mercenaria in Ampelisca mats of the southeastern Raritan Bay (New Jersey). We suggest that the Haploops habitat offers a broader diversity and quantity in food sources and that the Haploops tubes act as a substrate for MPB species. These results are supported by several mesocosm experiments designed to disentangle impacts of species assemblages and environmental characteristics on MPB biomass and production. For example, Dyson et al. (2007) showed that the sedimentary patchiness in OM enrichment affects macrofaunal (diversity and abundance) distribution, which in turn affects MPB production. With similar experiments, Hicks et al. (2011) showed that changes in grazing invertebrate assemblages are likely to influence MPB biomass. These investigations highlighted that in complex systems, such as natural habitats engineered by a tubicolous species, changes in species composition could fundamentally influence the resource provision and its utilisation and, ultimately, the equilibrium between autotrophic and heterotrophic production.

Benthic organisms from adjacent habitats largely benefit from benthic primary production in Haploops sediments, as the overall isotopic space is similar between the 2 habitats (see convex hull area of species isotopic compositions in Fig. 3), and the isotopic $\delta^{13} \mathrm{C}$ signature of the SOM in adjacent sediments did not show enriched $\delta^{13} \mathrm{C}$ values. Despite very low benthic primary production in the adjacent Amphiura habitat, resuspended microbenthic algae are the major diet component of the most dominant species in the bare sediment, the amphiurid A. filiformis, and significantly support the secondary production of the bare sediment. Haploops habitats, and potentially all large tube mats in muddy coastal systems, appear to be food exporters to adjacent communities. This study reveals that benthic habitats engineered by species potentially have strong trophic connections with surrounding habitats, and can, because of their biological activity, export primary production. This supports the definition of engineer species not only as species modifying diversity and species assemblages but also as species with the capacity to directly or indirectly control resources for other species (Allen \& Williams 2003).
Acknowledgements. We thank J. D. Gaffet, A. Brind'Amour, P. Laffargue, X. Caisey and the crew of the RV 'Thalia' for help at sea and providing logistic support. D. Delmas is thanked for analytical help of sediment. We also thank C. Gelpi for English grammar editing. Three reviewers greatly improved the quality of the manuscript. S.F.D. was funded by a grant from the EC2CO National Program on Coastal Environments and by the Total Foundation for Biodiversity and the Sea, and C.R. was funded by a PhD grant from the Region Bretagne.

\section{LITERATURE CITED}

Allen BJ, Williams SL (2003) Native eelgrass Zostera marina controls growth and reproduction of an invasive mussel through food limitation. Mar Ecol Prog Ser 254:57-67

Aminot A, Kérouel R (2004) Hydrologie des écosystèmes marins: paramètres et analyses. Editions Ifremer, France

> Baeta A, Valiela I, Rossi F, Pinto R, Richard P, Niquil N, Marques JC (2009) Eutrophication and trophic structure in response to the presence of the eelgrass Zostera noltii. Mar Biol 156:2107-2120

Barbier EB, Hacker SD, Kennedy C, Koch EW, Stier AC, Silliman BR (2011) The value of estuarine and coastal ecosystem services. Ecol Monogr 81:169-193

Barille L, Cognie B (2000) Revival capacity of diatoms in bivalve pseudofaeces and faeces. Diatom Res 15:11-17

Bearhop S, Adams CE, Waldron S, Fuller RA, MacLeod H (2004) Determining trophic niche width: a novel approach using stable isotope analysis. J Anim Ecol 73: 1007-1012

Berkenbusch K, Rowden AA (2007) An examination of the spatial and temporal generality of the influence of ecosystem engineers on the composition of associated assemblages. Aquat Ecol 41:129-147

Cabana G, Rasmussen JB (1996) Comparison of aquatic food chains using nitrogen isotopes. Proc Natl Acad Sci USA 93:10844-10847

Cahoon LB (1999) The role of benthic microalgae in neritic ecosystems. Oceanogr Mar Biol Annu Rev 37:47-86

Carefoot TH (1987) Aplysia: its biology and ecology. Oceanogr Mar Biol Annu Rev 25:167-284

Carlier A, Riéra P, Amouroux JM, Bodiou JY, Grémare A (2007) Benthic trophic network in the Bay of Banyuls-surMer (northwest Mediterranean, France): an assessment based on stable carbon and nitrogen isotopes analysis. Estuar Coast Shelf Sci 72:1-15

Caut S, Angulo E, Courchamp F (2009) Variation in discrimination factors $\left(\Delta^{15} \mathrm{~N}\right.$ and $\left.\Delta^{13} \mathrm{C}\right)$ : the effect of diet isotopic values and applications for diet reconstruction. J Appl Ecol 46:443-453

> Cloern JE, Dufford R (2005) Phytoplankton community ecology: principles applied in San Francisco Bay. Mar Ecol Prog Ser 285:11-28

Colombo F, Costa V, Dubois SF, Gianguzza P, Mazzola A, Vizzini S (2013) Trophic structure of vermetid reef community: high trophic diversity at small spatial scales. J Sea Res 77:93-99

> Cornwell WK, Schwilk DW, Ackerly DD (2006) A trait-based test for habitat filtering: convex hull volume. Ecology 87 : 1465-1471

Costanza R, D'Arge R, De Groot R, Farber S and others (1997) The value of the world's ecosystem services and natural capital. Nature 387:253-260 
Cui X, Grebmeier JM, Cooper LW (2012) Feeding ecology of dominant groundfish in the northern Bering Sea. Polar Biol 35:1407-1419

Dando PR, Spiro B (1993) Varying nutritional dependence of the thyasirid bivalves Thyasira sarsi and T. equalis on chemoautotrophic symbiotic bacteria, demonstrated by isotope ratios of tissue carbon and shell carbonate. Mar Ecol Prog Ser 92:151-158

Desaunay Y, Guerault D, Le Pape O, Poulard JC (2006) Changes in occurrence and abundance of northern/ southern flatfishes over a 20 -year period in a coastal nursery area (Bay of Vilaine) and on the eastern continental shelf of the Bay of Biscay. Sci Mar 70:193-200

Dubois SF, Grall J (2013) Preface. Contributions to the 8th International Conference on Applications of Stable Isotope Techniques to Ecological Studies (ISOECOL), Brest, France, 20-24 August 2012. Isotopes Environ Health Studies 49:293-294

> Dubois SF, Marín-Léal JC, Ropert M, Lefebvre S (2007) Effects of oyster farming on macrofaunal assemblages associated with Lanice conchilega tubeworm populations: a trophic analysis using natural stable isotopes. Aquaculture 271:336-349

Duffy JE, Cardinale BJ, France KE, McIntyre PB, Thebault E, Loreau M (2007) The functional role of biodiversity in ecosystems: incorporating trophic complexity. Ecol Lett 10:522-538

> Dufour SC, Felbeck H (2006) Symbiont abundance in thyasirids (Bivalvia) is related to particulate food and sulphide availability. Mar Ecol Prog Ser 320:185-194

> Dyson KE, Bulling MT, Solan M, Hernandez-Milian G, Raffaelli DG, White PCL, Paterson DM (2007) Influence of macrofaunal assemblages and environmental heterogeneity on microphytobenthic production in experimental systems. Proc Biol Sci 274:2547-2554

> Ehrhold A, Hamon D, Guillaumont B (2006) The REBENT monitoring network, a spatially integrated, acoustic approach to surveying nearshore macrobenthic habitats: application to the Bay of Concarneau (south Brittany, France). ICES J Mar Sci 63:1604-1615

> Emmerson M, Yearsley JM (2004) Weak interactions, omnivory and emergent food-web properties. Proc Biol Sci 271:397-405

Evrard V, Soetaert K, Heip CHR, Huettel M, Xenopoulos MA, Middelburg JJ (2010) Carbon and nitrogen flows through the benthic food web of a photic subtidal sandy sediment. Mar Ecol Prog Ser 416:1-16

> Evrard V, Huettel M, Cook PLM, Soetaert K, Heip CHR, Middelburg JJ (2012) Importance of phytodetritus and microphytobenthos for heterotrophs in a shallow subtidal sandy sediment. Mar Ecol Prog Ser 455:13-31

Fanelli E, Cartes JE, Badalamenti F, Rumolo P, Sprovieri M (2009) Trophodynamics of suprabenthic fauna on coastal muddy bottoms of the southern Tyrrhenian Sea (western Mediterranean). J Sea Res 61:174-187

$>$ Franz DR, Tanacredi JT (1992) Secondary production of the amphipod Ampelisca abdita Mills and its importance in the diet of juvenile winter flounder (Pleuronectes americanus) in Jamaica Bay, New York. Estuaries 15:193-203

> Fry B (2013) Alternative approaches for solving underdetermined isotope mixing problems. Mar Ecol Prog Ser 472: $1-13$

Gattuso JP, Frankignoulle M, Wollast R (1998) Carbon and carbonate metabolism in coastal aquatic ecosystems. Annu Rev Ecol Syst 29:405-434
Glémarec M (1969) Les peuplements benthiques du plateau continental Nord-Gascogne. Thèse d'Etat de l'Université de Bretagne Occidentale, Brest

> Göransson P (2002) Petersen's benthic macrofauna stations revisited in the Oresund area (southern Sweden) and species composition in the 1990s-signs of decreased biological variation. Sarsia 87:263-280

- Grall J, Le Loc'h F, Guyonnet B, Riera P (2006) Community structure and food web based on stable isotopes $\left(\delta^{15} \mathrm{~N}\right.$ and $\delta^{13} \mathrm{C}$ ) analysis of a north eastern Atlantic maerl bed. J Exp Mar Biol Ecol 338:1-15

> Grebmeier JM, McRoy CP (1989) Pelagic-benthic coupling on the shelf of the northern Bering and Chukchi Seas. III. Benthic food supply and carbon cycling. Mar Ecol Prog Ser 53:79-91

Grippo MA, Fleeger JW, Dubois SF, Condrey RA (2011) Spatial variation in basal resources supporting benthic food webs revealed for the inner continental shelf. Limnol Oceanogr 56:841-856

- Hicks N, Bulling M, Solan M, Raffaelli D, White PCL, Paterson DM (2011) Impact of biodiversity-climate futures on primary production and metabolism in a model benthic estuarine system. BMC Ecol 11:7

Highsmith RC, Coyle KO (1992) Productivity of arctic amphipods relative to gray whale energy requirements. Mar Ecol Prog Ser 83:141-150

- Hobson KA, Fisk A, Karnovsky N, Holst M, Gagnon JM, Fortier M (2002) A stable isotope $\left(\delta^{13} \mathrm{C}, \delta^{15} \mathrm{~N}\right)$ model for the North Water food web: implications for evaluating trophodynamics and the flow of energy and contaminants. Deep-Sea Res II 49:5131-5150

Irlandi EA, Peterson CH (1991) Modification of animal habitat by large plants: mechanisms by which seagrasses influence clam growth. Oecologia 87:307-318

> Jones CG, Lawton JH, Shachak M (1994) Organisms as ecosystem engineers. Oikos 69:373-386

> Kopp D, Le Bris H, Grimaud L, Nérot C, Brind'Amour A (2013) Spatial analysis of the trophic interactions between two juvenile fish species and their preys along a coastal-estuarine gradient. J Sea Res 81:40-48

Layman CA, Arrington DA, Montana CG, Post DM (2007a) Can stable isotope ratios provide quantitative measures of trophic diversity within food webs? Ecology 88:42-48

Layman CA, Quattrochi JP, Peyer CM, Allgeier JE (2007b) Niche width collapse in a resilient top predator following ecosystem fragmentation. Ecol Lett 10:937-944

> Layman CA, Araujo MS, Boucek R, Hammerschlag-Peyer $\mathrm{CM}$ and others (2012) Applying stable isotopes to examine food-web structure: an overview of analytical tools. Biol Rev Camb Philos Soc 87:545-562

> Le Loc'h F, Hily C, Grall J (2008) Benthic community and food web structure on the continental shelf of the Bay of Biscay (North Eastern Atlantic) revealed by stable isotopes analysis. J Mar Syst 72:17-34

- Lefebvre S, Marín-Leal JC, Dubois S, Orvain F and others (2009) Seasonal dynamics of trophic relationships among co-occurring suspension-feeders in two shellfish-culture dominated ecosystems. Estuar Coast Shelf Sci 82: 415-425

> Long ZT, Bruno JF, Duffy JE (2011) Food chain length and omnivory determine the stability of a marine subtidal food web. J Anim Ecol 80:586-594

> Lorenzen CJ (1967) Determination of chlorophyll and phaeopigment spectrophotometric equations. Limnol Oceanogr 12:343-346 
MacKenzie CL Jr., Pikanowski R, McMillan DG (2006) Ampelisca amphipod tube mats may enhance abundance of northern quahogs Mercenaria mercenaria in muddy sediments. J Shellfish Res 25:841-847

> Marín Leal JC, Dubois S, Orvain F, Galois R and others (2008) Stable isotopes $\left(\delta^{13} \mathrm{C}, \delta^{15} \mathrm{~N}\right)$ and modelling as tools to estimate the trophic ecology of cultivated oysters in two contrasting environments. Mar Biol 153:673-688

McCutchan JH, Lewis WM, Kendall C, McGrath CC (2003) Variation in trophic shift for stable isotope ratios of carbon, nitrogen, and sulfur. Oikos 102:378-390

Ménesguen A (1980) La macrofaune benthique de la baie de Concarneau: peuplements, dynamique de populations, prédation exercée par les poissons. PhD thesis, Université de Bretagne Occidentale

Middelburg JJ, Barranguet C, Boschker HTS, Herman PMJ, Moens T, Heip CHR (2000) The fate of intertidal microphytobenthos carbon: an in situ ${ }^{13} \mathrm{C}$-labeling study. Limnol Oceanogr 45:1224-1234

Mills EL (1967) Biology of an ampeliscid amphipod crustacean sibling species pair. J Fish Res Board Can 24: 305-355

Mills LS, Soule ME, Doak DF (1993) The keystone-species concept in ecology and conservation. Bioscience 43: 219-224

Minagawa M, Wada E (1984) Stepwise enrichment of ${ }^{15} \mathrm{~N}$ along food chains: further evidence and the relation between $\delta^{15} \mathrm{~N}$ and animal age. Geochim Cosmochim Acta 48:1135-1140

Morin PJ, Lawler SP (1995) Food web architecture and population dynamics: theory and empirical evidence. Annu Rev Ecol Syst 26:505-529

Myers AA, Rigolet C, Thiébaut E, Dubois SF (2012) A new species of amphipod, Photis inornatus sp nov (Corophiidea, Photidae) from a 'Haploops community' in Brittany. Zootaxa 3236:55-61

Ní Longphuirt S, Clavier J, Grall J, Chauvaud L and others (2007) Primary production and spatial distribution of subtidal microphytobenthos in a temperate coastal system, the Bay of Brest, France. Estuar Coast Shelf Sci 74: 367-380

> Nyssen F, Brey T, Dauby P, Graeve M (2005) Trophic position of Antarctic amphipods - enhanced analysis by a 2dimensional biomarker assay. Mar Ecol Prog Ser 300: 135-145

> Parnell AC, Inger R, Bearhop S, Jackson AL (2010) Source partitioning using stable isotopes: coping with too much variation. PLoS ONE 5:e9672

Peterson BJ (1999) Stable isotopes as tracers of organic matter input and transfer in benthic food webs: a review. Acta Oecol 20:479-487

Peterson BJ, Fry B (1987) Stable isotopes in ecosystem studies. Annu Rev Ecol Syst 18:293-320

Phillips DL (2012) Converting isotope values to diet composition: the use of mixing models. J Mammal 93: 342-352

Phillips DL, Gregg J (2003) Source partitioning using stable isotopes: coping with too many sources. Oecologia 136: 261-269

Editorial responsibility: Martin Solan, Southampton, UK
Post DM (2002) Using stable isotopes to estimate trophic position: models, methods, and assumptions. Ecology 83: 703-718

R Development Core Team (2010) R: A language and environment for statistical computing, reference index, version 2.11.1. R Foundation for Statistical Computing, Vienna

Redfield AC, Ketchum BH, Richards FA (1963) The influence of organisms on the composition of seawater. In: Hill MN (ed) The sea, Vol 2. Wiley, New York, NY, p 26-77

Reise K, Bouma TJ, Olenin S, Ysebaert T (2009) Coastal habitat engineers and the biodiversity in marine sediments. Helgol Mar Res 63:1-2

Riera P, Richard P (1996) Isotopic determination of food sources of Crassostrea gigas along a trophic gradient in the estuarine Bay of Marennes-Oleron. Estuar Coast Shelf Sci 42:347-360

> Riera P, Richard P, Grémare A, Blanchard G (1996) Food source of intertidal nematodes in the Bay of MarennesOleron (France), as determined by dual stable isotope analysis. Mar Ecol Prog Ser 142:303-309

> Rigolet C, Le Souchu P, Caisey X, Dubois SF (2011) Group sweeping: feeding activity and filtration rate in the tubicolous amphipod Haploops nirae (Kaim-Malka, 1976). J Exp Mar Biol Ecol 406:29-37

Rigolet C, Dubois SF, Droual G, Caisey X, Thiébaut E (2012) Life history and secondary production of the amphipod Haploops nirae (Kaim-Malka, 1976) in the Bay of Concarneau (south Brittany). Estuar Coast Shelf Sci 113:259-271

Rigolet C, Dubois SF, Thiébaut E (2014) Benthic control freaks: effects of the tubiculous amphipod Haploops nirae on structural and functional diversity of benthic communities. J Sea Res 85:413-427

Ross ON, Sharples J (2007) Phytoplankton motility and the competition for nutrients in the thermocline. Mar Ecol Prog Ser 347:21-38

Vander Zanden MJ, Rasmussen JB (2001) Variation in $\delta^{15} \mathrm{~N}$ and $\delta^{13} \mathrm{C}$ trophic fractionation: implications for aquatic food web studies. Limnol Oceanogr 46:2061-2066

> Vander Zanden MJ, Cabana G, Rasmussen JB (1997) Comparing trophic position of freshwater littoral fish species using stable nitrogen isotopes $\left(\delta^{15} \mathrm{~N}\right)$ and literature dietary data. Can J Fish Aquat Sci 54:1142-1158

Vanderklift MA, Ponsard S (2003) Sources of variation in consumer-diet delta ${ }^{15} \mathrm{~N}$ enrichment: a meta-analysis. Oecologia 136:169-182

Villéger S, Mason NWH, Mouillot D (2008) New multidimensional functional diversity indices for a multifaceted framework in functional ecology. Ecology 89:2290-2301

> Voultsiadou E, Pyrounaki MM, Chintiroglou CH (2007) The habitat engineering tunicate Microcosmus sabatieri (Roule, 1885) and its associated peracarid epifauna. Estuar Coast Shelf Sci 74:197-204

Wright JP, Jones CG (2006) The concept of organisms as ecosystem engineers ten years on: progress, limitations and challenges. Bioscience 56:203-209

Zambrano LE, Valiente M, Vander Zanden J (2010) Stable isotope variation of a highly heterogeneous freshwater system. Hydrobiologia 646:327-336

Submitted: June 14, 2013; Accepted: December 12, 2013

Proofs received from author(s): February 27, 2014 